\section{GEOPHYSICAL CONSTRAINTS ON THE DEEP STRUCTURE ALONG THE ECORS PYRENEES LINE}

\author{
M. Daignieres, ${ }^{1}$ B. de Cabissole, ${ }^{1}$ \\ J. Gallart, ${ }^{2}$ A. Hirn, ${ }^{3}$ \\ E. Surinach, ${ }^{4}$ and M. Torne ${ }^{5}$
}

\begin{abstract}
The structure of the central part of the Pyrenean range, traversed by the ECORS vertical reflection seismic line, is further constrained by a joint interpretation of complementary and reprocessed data. Wide-angle, low-frequency profiling of Moho topography indicates an abrupt termination of the northern, European Moho at the North Pyrenean fault and a range of possible geometries of a deeper, Iberian Moho which does not seem to extend significantly to the north of this fault. When reprocessing vertical reflection data to $25 \mathrm{~s}$ two-way travel time, strong clear straight reflections are discovered in the part of the section under the northern foreland, long after the Moho reflection. Their strong northward dip indicates that they originate in fact at reflectors at depth beneath the North Pyrenean fault, which may correspond to the connection between the two levels of Moho, the reflections then being from the northward inclined
\end{abstract}

\footnotetext{
${ }^{1}$ Centre Géophysique et Géologique, Université des Sciences et Techniques du Languedoc, Montpellier, France.

${ }^{2}$ Instituto de Geologia Jaime Almera, Barcelona, Spain.

${ }^{3}$ Institut de Physique du Globe, Université Pierre et Marie Curie, Paris.

${ }^{4}$ Catedra de Geofisica, Universidad Complutense, Madrid.

${ }^{5}$ Servei Geologic de Catalunya, Barcelona, Spain.

Copyright 1989

by the American Geophysical Union.

Paper number 89tc00863.

0278-7407/89/89tc-00863\$10.00
}

limit between the wedge of Iberian crust underlying the southern edge of the European mantle. A range of possible shapes is allowed by the conjunction of these seismic data, which is compatible with the results of a detailed gravity profile. This would indicate that the imbrication of European into Iberian lithosphere has been of limited extent with respect to the surface trace of the North Pyrenean fault, provided no strong density contrast in the mantle part of the section contributes significantly to the gravity anomaly.

\section{INTRODUCTION}

The ECORS vertical reflection seismic survey carried out in 1985 and 1986 across the Pyrenees was designed to constrain the possible structural models of this mountain range. Classicaly, the structural zones of the Pyrenees have been defined [Mattauer, 1968], from north to south, as follows. The Aquitanian molassic foreland is overthrust from the south (along the Northern Pyrenean Frontal Thrust) by the North Pyrenean Zone (NPZ), including Mesozoic flysch deposits and Hercynian basement cores (the North Pyrenean Massifs). This zone is bounded to the south by the vertically faulted North Pyrenean fault (NPF) zone running east-west along the belt, locally with highly strained Mesozoic metamorphic rocks. The Axial Zone (the highest part of the chain) is made of Hercynian material reworked during the Alpine orogeny by a southward directed thrust system. In the South Pyrenean Zone, Mesozoic and Cenozoic rocks, belonging to a large detached unit, are overthrust to the south over the Ebro molassic basin in the vicinity of the Sierras Marginales. For more details see Choukroune et al. [1989].

The section obtained displays well-defined intracrustal reflectors in a general fan shape geometry; the 
structures of the northern and southern forelands are well imaged, while the central part, beneath the Pyrenean Axial Zone (PAZ) shows weaker and more interfering reflections [ECORS Pyrenees Team, 1988]. However, the deep structure under this central zone is a key to the structural model of the orogen. Reliable constraints on the size, shape, and composition of the crustal root and its relations to the NPF are a perequisite to the construction of balanced cross sections through the range, if these are to depict the whole crust and not overemphasize superficial details. As illustrated by Plate 1 by Choukroune et al. [1989], deep seismic reflection provides outstanding elements of deep geometry; yet they do not completely determine the lithospheric model at depth. We intend here to add data from processing of the vertical reflection from 15 to $25 \mathrm{~s}$ two-way travel time (TWT), from wide-angle low-frequency seismic reflection, and show how a joint interpretation with gravity, also newly completed as part of the ECORS program [Torne et al. 1989], allows us to reduce the variety of acceptable models of the present constitution of the lithosphere and hence of its evolution.

\section{PREVIOUS WORK}

Early gravity data [Coron and Guillaume, 1971] gave indications of the existence of a crustal root, but they were too scarce and the crustal structure too loosely known to lead to a constrained structural picture. Knowledge of the average crustal structure and thickness was provided by a large-scale explosion seismology survey (refraction and wide-angle reflection) in 1978 [Gallart et al., 1980, 1981; Daignières et al., 1981, 1982]. The first-order results were the determination of a crustal thickness of $50 \mathrm{~km}$ under the PAZ and of only 28 to $35 \mathrm{~km}$ under the NPZ. To resolve the nature of the transition between these strongly different regions, fan shooting was used broadside into lines of receivers across the NPF at wide-angle reflection offsets [Him et al., 1980]. This resulted in two sections of the topography of the Moho (crust-mantle boundary), one of which was approximately colinear with the ECORS Pyrenees vertical reflection line [see Hirn et al., 1980, Figure 5]. This section showed the clear Moho of the northern domain at $33 \mathrm{~km}$ depth, brutally interrupted over less than 10-km horizontal distance at the latitude of the NPF; the southern Moho of the PAZ was situated there over $15 \mathrm{~km}$ deeper. At that time the simplest interpretation of this Moho step just under the surface limit between PAZ and NPZ was in favor of a sharp, and in the absence of other argument, essentially vertical limit between the two crustal segments. Nevertheless, the position of the shot point, just at the vertical of the southern limit of the shallow Moho, was such that this could have hidden deeper reflections such as those due to a possible northern prolongation of the 50-km-deep southern Moho from which waves could have been screened off by reflections on the shallower crustal segment.
So the opportunity in the ECORS project to carry out a vertical reflection profile across the Pyrénées in this same region was invaluable, as it could bring a much finer resolution of structures mainly within the crust and possibly at Moho depth. However, for this deeper target this survey appeared insufficient and was supplemented with a dense coverage of new gravity stations [Torné et al., 1989] and a new wide-angle reflection experiment to try to elucidate it further.

\section{NEW SEISMIC DATA AND THEIR INTERPRETATION}

In October 1987 a new wide-angle reflection profile at constant offset was carried out by fan shooting. The shot point was this time chosen $35 \mathrm{~km}$ south of the NPF, at Bielsa, far south from the known southern extremity of the shallower northern Moho. If the southern deeper Moho extended further north than the surface trace of the NPF, that is, under the northem shallower Moho, the location of the shot point would this time allow us to undershoot the shallow Moho and sample reflections from the deeper Moho further north (Figure 1). Furthermore, as offsets used previously in the NPZ were on the order of $100 \mathrm{~km}$, adapted to reflector depths around $30 \mathrm{~km}$, which might also have been a reason for the absence of reflection on deeper interfaces, this time a $200-\mathrm{km}$ offset was used to enhance the response of such reflectors as the deeper Moho of the PAZ, if present. A 1.5-ton charge, recorded with the geometry of Figure 2 provided the fan profile data of Figure 3.

From trace 8 to 31 a clear reflection on a subhorizontal Moho appears. For the mean crustal velocity of $6.25 \mathrm{~km} / \mathrm{s}$ of Daignières et al.[1981] the Moho depth on the ECORS line is $37 \mathrm{~km}$ just north of the NPF. This reflector is suddenly interrupted toward the south, while it is well defined along the $30 \mathrm{~km}$ to the north, deepening to $39 \mathrm{~km}$ under the North Pyrenean Massif of the Arize. On the ECORS vertical reflection section this feature can be associated with the prominent reflections around $11.5 \mathrm{~s}$ TWT [Choukroune et al., 1989, Figure 5].

A much later wide-angle Moho reflection is obtained in the south. It is seen toward the north at least to trace 8. The fan profile could not be extended far enough to the south to sample a segment of reflector adequate to identify its dip. If it were locally horizontal, it would extend just beneath the surface trace of the NPF at a depth of $55 \mathrm{~km}$ if the same average crustal velocity as for the northern thinner crust is taken, or at a depth of $58 \mathrm{~km}$ with an average crustal velocity of $6.4 \mathrm{~km} / \mathrm{s}$, which would correspond to a crust thickened mainly in its lower part; it is the $M$ case in Figure 4. The Moho could also have a northward dip, as might be suggested by the comparison with the vertical reflection section if the general facies of weak dicontinuous energy displayed by this section, at times in excess of $15 \mathrm{~s}$ TWT, is attributed to reflections [see Choukroune et al., 1989, plate 1]. In this case, wide-angle reflections should be migrated, with the hypothesis used, 


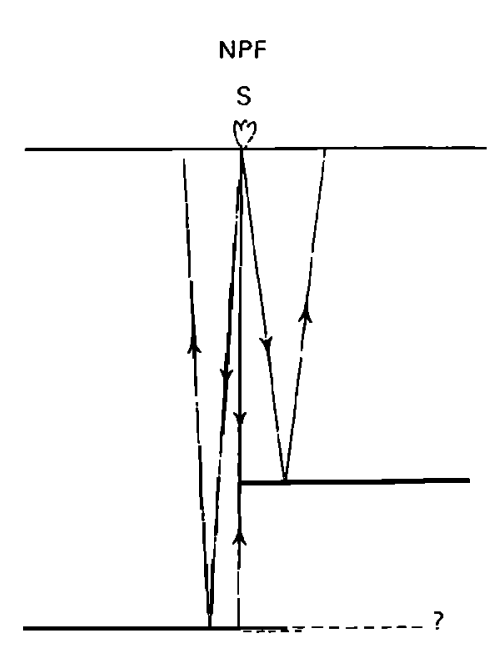

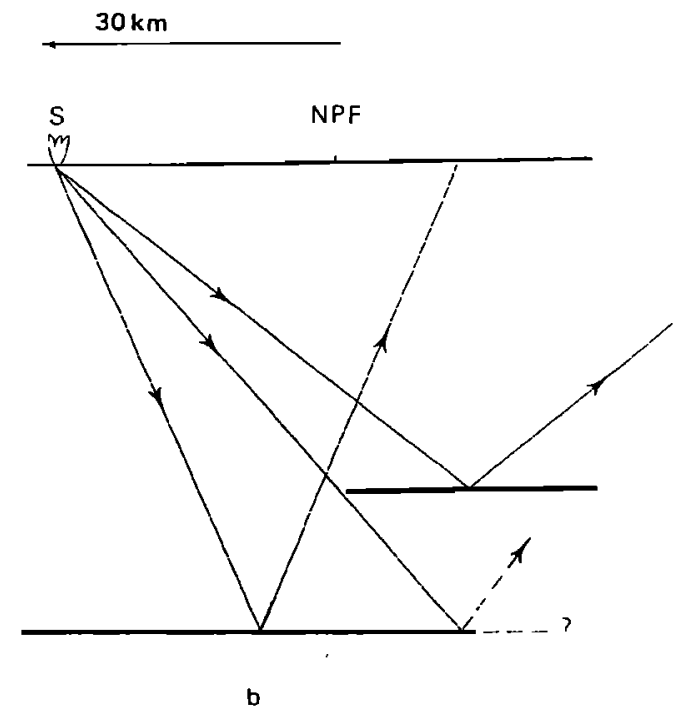

Fig. 1. Ray geometries for two different positions of the shot point $S$ with respect to the extremity of the shallow Moho north of the Pyrenees (projection sketched on a north-south plane; to work in the wide-angle reflection range the shot point and the recorders are in fact situated $100 \mathrm{~km}$ on either side of the plane of the figure. See Figure 2 for plane view). Continuation of the deeper Moho beneath the shallow one may (a) have been hidden in previous experiments by geometrical screening of rays and (b) be sampled in present experiment by undershooting.

also in vertical reflection seismics, of the strike of the structures being perpendicular to the plane of the section. This would define the Moho in a depth section with a northward dip around $10^{\circ}$ and situated slightly shallower, $52 \mathrm{~km}$, and $20 \mathrm{~km}$ south of the NPF toward which the deep Moho then would not have been sampled; it is the M' case in Figure 4. For each one of the two possible interpretations, constraints on the depth, dip, and minimum extent toward the north of the deep Moho were obtained.

Previous processing of the northern part of the ECORS vertical reflection section [see ECORS Pyrenees Team, 1988, Figure 3] was limited to $16 \mathrm{~s}$ TWT. To investigate the existence of deeper reflections a new processing was carried to the maximum possible of $25 \mathrm{~s}$ TWT on this segment north of the Pyrenees. This led to the discovery of very strong, continuous and linear reflections dipping north from 13 to $22 \mathrm{~s}$ TWT over a $35 \mathrm{~km}$ horizontal distance, as displayed in Figure 5 (for comments on the other reflectors see Choukroune et al. [1989]). Such clear continuous reflections, at times in excess of those of the Moho reflection, have already been observed, the best documented case being the Flannan Thrust, north of Scotland, [McGeary and Warner, 1985], clearly situated, after migration, deeper than the Moho, within the mantle. In the Pyrenean section the very strong dip in the time section indicates that the real reflector is largely situated south of the seismic common-depthpoint (CDP) where it appears, beneath the Aquitaine Basin, in the time section. Whatever velocity is taken, ranging from crust to mantle values, the reflections, if considered as strictly linear, are so inclined that they migrate to define a very steep interface at depth under the NPF, although no lateral control allows us to be sure that migration should be strictly in the plane of the section. The two extreme locations of this reflector in Figure 4 (obtained by line-drawing migration) assume either a propagation through only crustal rocks with an average velocity of $6.25 \mathrm{~km} / \mathrm{s}$, giving location 1 , or a propagation through a large proportion of mantle material, resulting in an average velocity along the path of $7.3 \mathrm{~km} / \mathrm{s}$, giving location 2 . Location 1 is obviously unrealistic because it implies a lack of mantle material beneath the European Moho, the true location is more likely next to location 2 . In any case, this reflector is situated geographically and in depth in between the southem extremity of the shallow northern Moho and the northern extremity of the deep southern Moho, as defined by wide-angle reflection. Its situation under the tip of the shallow Moho would suggest that this reflector is overlain by mantle material; it should then be underlain by crustal material to provide a sufficient impedance contrast for vertical reflection. This interpretation is also supported by the fact that no corresponding reflection is identified on the wide-angle section, which is only compatible with a negative and not positive step in velocity with depth across it. We claim that the simplest interpretation of this reflector is neither an intracrustal nor an intramantle interface but a boundary from mantle to crust which occurs between the mantle underlying the shallow Moho north of the NPF and the crust overlying the deep Moho south of it. 


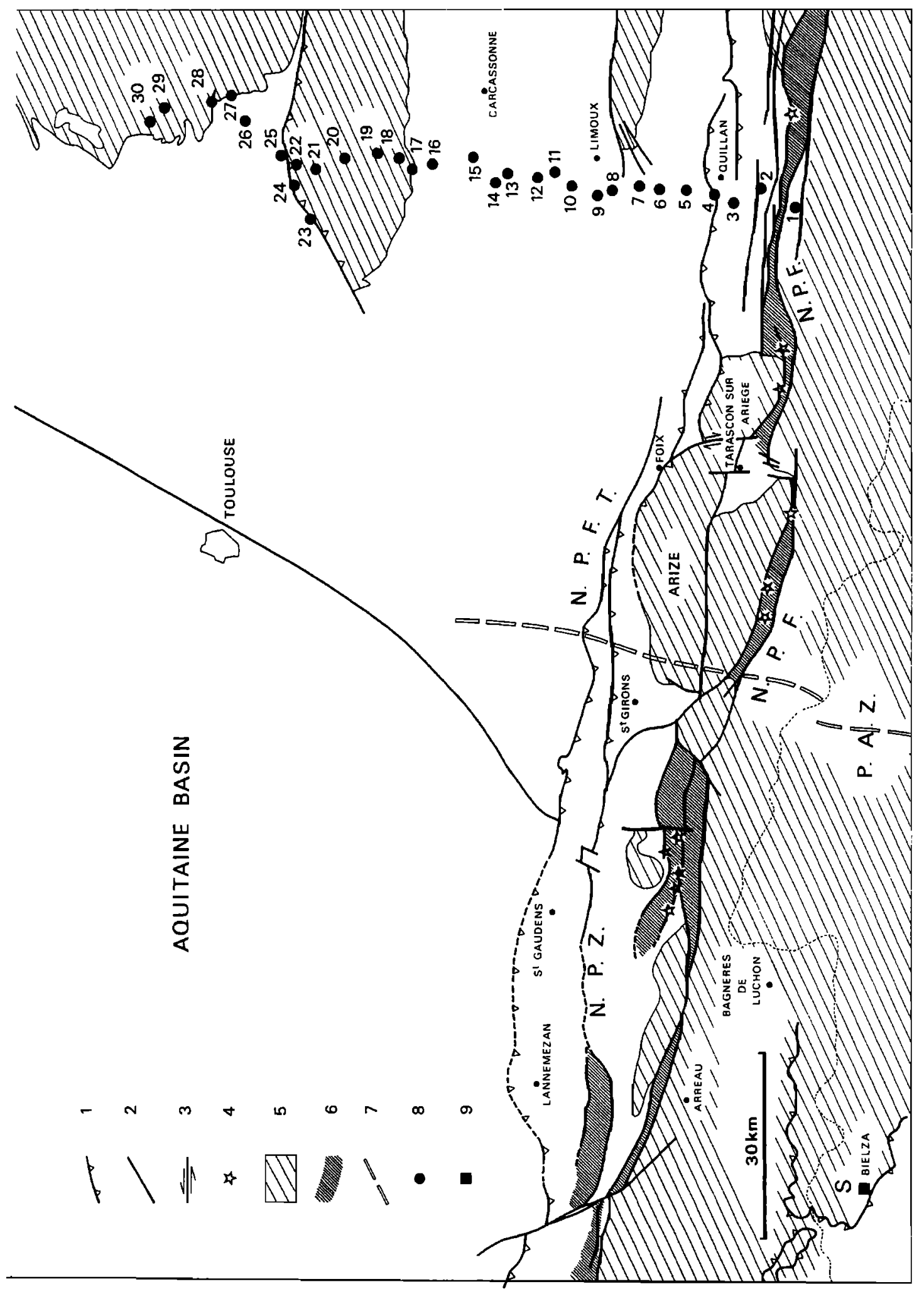

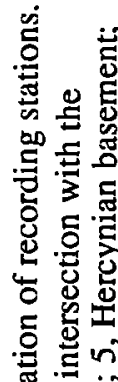

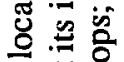

击要

崖手

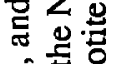

s.

乙寻

\pm \&

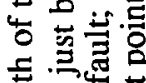

융

E ธิ ปे

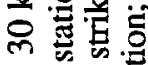

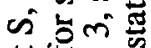

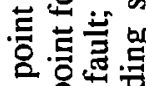

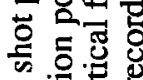

든

案总

市造吉

월

के 홀

.

远

焉至

क人

둥옹

号和

उप

央造总

可矛

늉명

昰的

i 至范章 ดั 


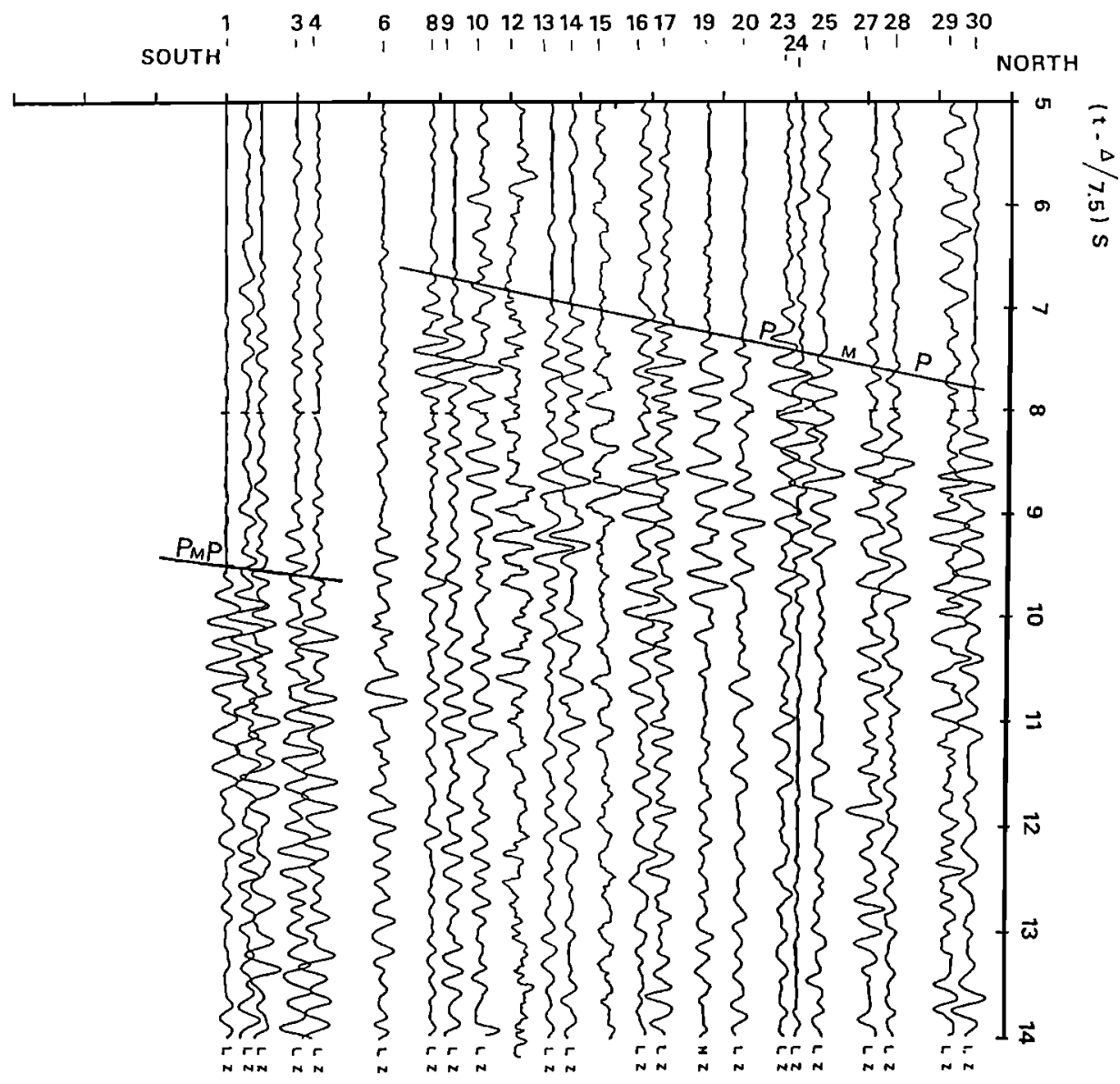

Fig. 3. North-south time section obtained at $200 \mathrm{~km}$ offset, displayed with a reduction velocity of $7.5 \mathrm{~km} / \mathrm{s}$. Note for traces 8 to 30 the clear PMP reflections on the shallow northern Moho between 7 and $8 \mathrm{~s}$ reduced time and on traces 1 to 4 the late reflections at $9.5 \mathrm{~s}$ on the deeper Moho.

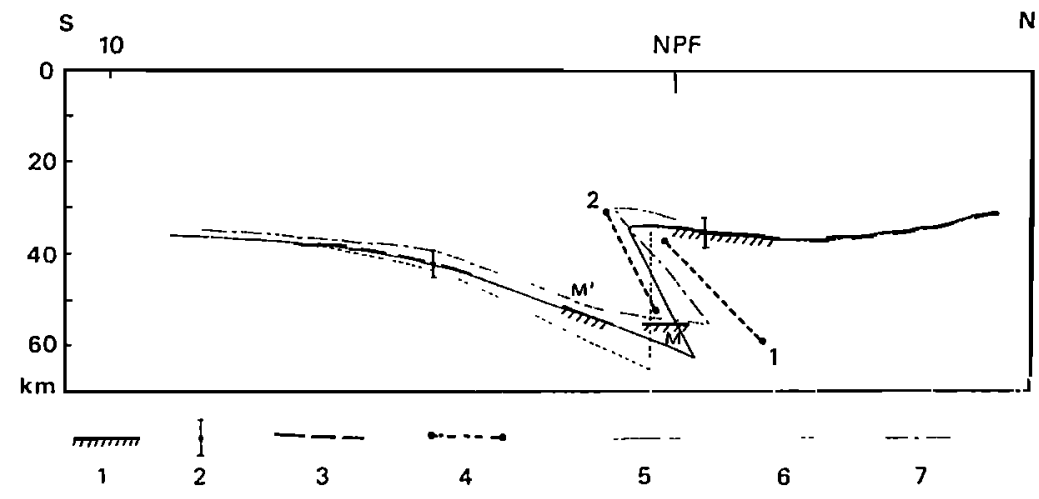

Fig. 4. Acceptable geometries of the crust-mantle interface across the Pyrenees from seismic constraints, with their range, under different assumptions. 1, Moho positions from wide-angle reflections (case $\mathrm{M}$ or $\mathbf{M}^{\prime}$ ); 2, Moho positions from refraction survey; 3 , well-identified reflective Moho from ECORS line; 4, two extreme locations (case 1 or 2 ) for the deep reflector of Figure $5 ; 5,6$, and 7, extreme crust-mantle interface locations compatible with gravity data [Torné et al., 1989]. 


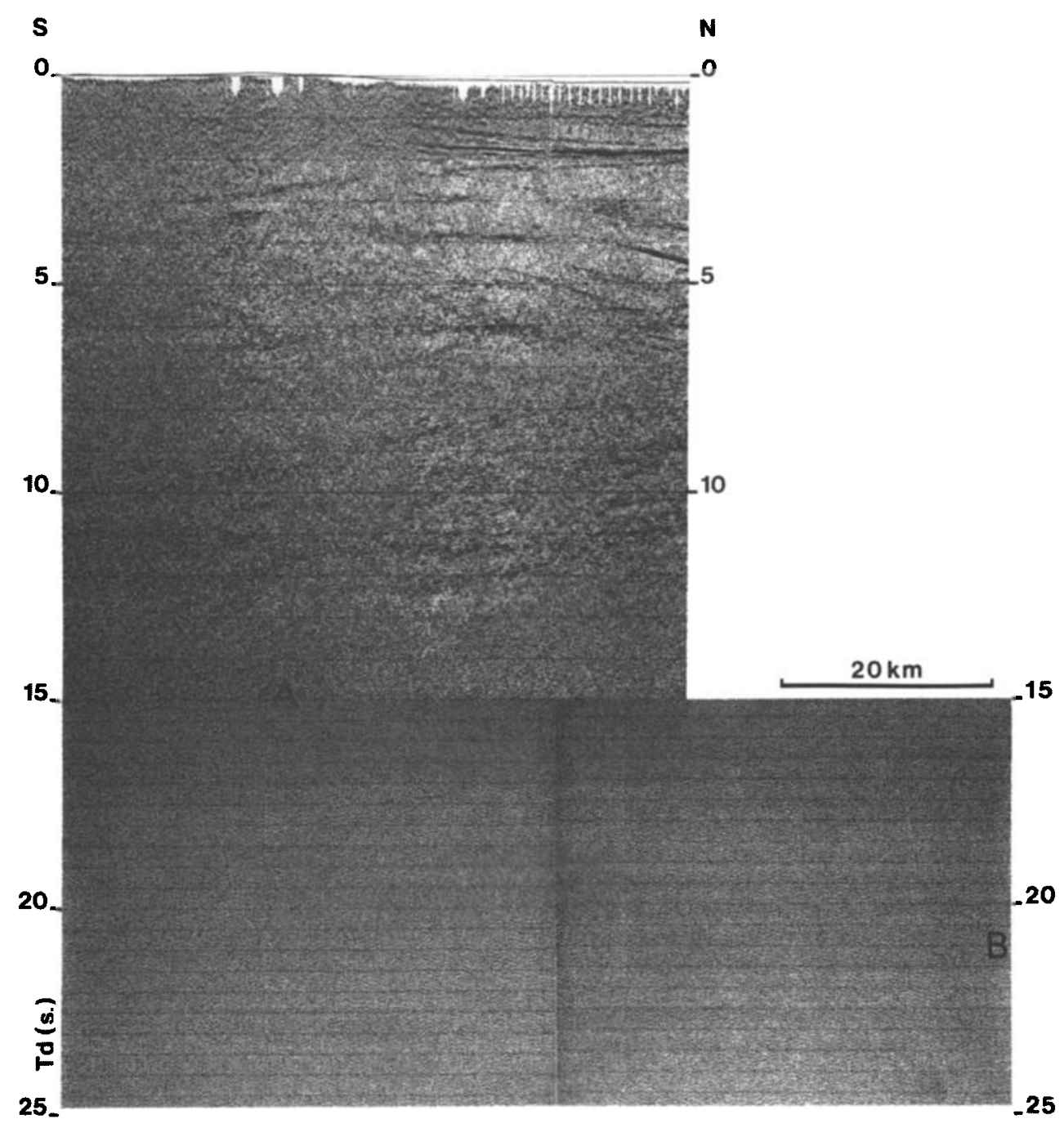

Fig. 5. Part of the vertical reflection section (unmigrated) processed to $25 \mathrm{~s}$ TWT. Note the very clear continuous and straight reflection between points $A$ and $B$ at very late times in excess of those of the locally 12-s deep Moho. It lies above a zone of increased reflectivity. Locations of this interface with extreme allowable migration velocities are shown as 1 and 2 in Figure 4.

Joint interpretation of wide-angle and vertical reflection seismic data does not uniquely determine the structural model but does allow us to place reliable constraints on the geometry and medium velocity or density ranging between extremes corresponding to an unresolvable variation in assumptions.

\section{GRAVITY MODELING AND DISCUSSION}

A total of 4020 gravity stations (645 of them were specially made for the ECORS survey) have been used to derive a Bouguer anomaly map (1 station each $6 \mathrm{~km}^{2}$ ) of the area [Torné et al., 1989]; a density of $2670 \mathrm{~kg} / \mathrm{m}^{3}$ was used for reduction, and the GRS 67 has been adopted as the reference ellipsoid. A Bouguer gravity profile was then computed by projecting the gravity values of a stripe $20 \mathrm{~km}$ wide and $220 \mathrm{~km}$ long containing the seismic line on the ECORS line (Figure 6a). It shows a negative anomaly (- $105 \mathrm{mgal}$ ) centered on the PAZ, disturbed by a local positive anomaly on the NPZ.

As morphology and filling densities of the basins on the north and south sides of the range are well known, gravity data will not contribute to a better definition of them and can be used only to constrain the morphology and depth of the Moho, the upper limit of the lower crust, and the heavy intracrustal bodies, especially in the central part of the ECORS line, where 


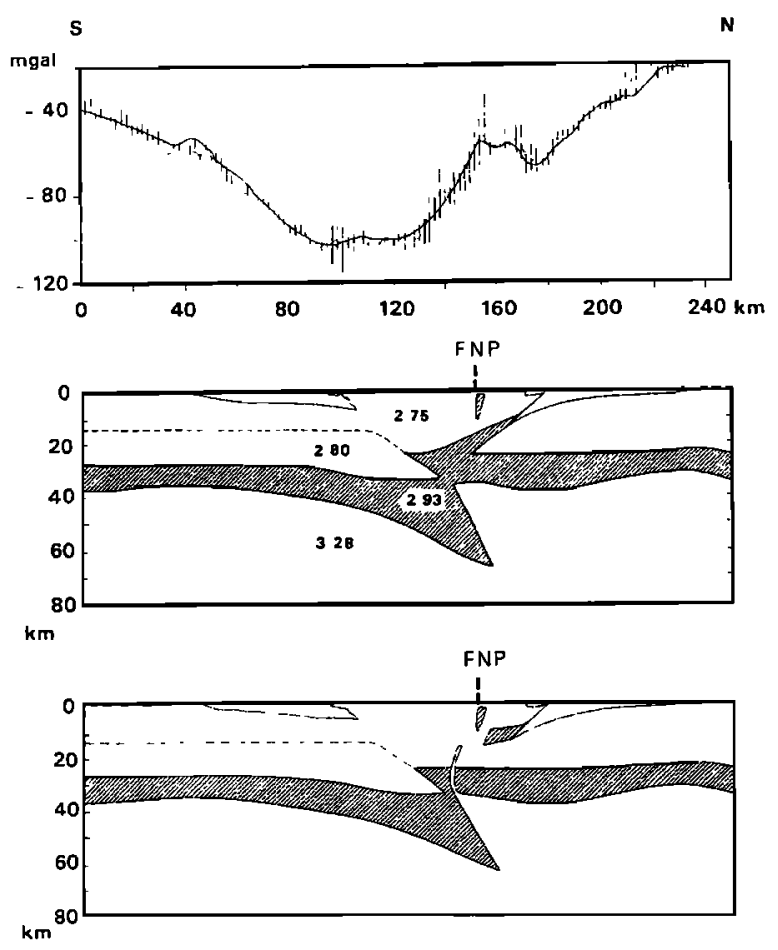

Fig. 6. (a) Mean Bouguer gravity data [Torné et al., 1989] along the ECORS line (fine curve), vertical bar indicates the standard deviation. Thick curve is the computed value of the Bouguer anomaly for models shown in Figures $6 \mathrm{~b}$ and $6 \mathrm{c}$. (b) and (c) Two density models compatible with both gravity and seismic data; they differ in their interpretation of the heavy intracrustal bodies beneath the surface trace of the NPF.

the seismic results are poor. Torné et al. [1989], used densities constrained by measurements on samples or well logging data, when available [Marchal, 1986], and refraction data [Daignières et al., 1982] for deeper layers (middle, lower crust and upper mantle) of this region and carried out two-dimensional gravity modeling.

Concerning the root shape and northward extent of the Iberian crust, all gravity compatible models lead to a wedge-shaped root, at $65 \mathrm{~km}$ depth beneath the NPF, with a northern limit of the Iberian crust ranging from a vertical to a $45^{\circ}$ north dipping interface (Figure 4, lines 6 and 7). When checked against the seismic constraints just reported, an intermediate solution, shown by line 5 in Figure 4, has to be preferred, with a $70^{\circ}$ north dipping limit. In this case, in order to achieve the fit to gravity it is necessary to extrapolate the northward dipping deep Moho (case M', Figure 4) at least to beneath the NPF, $20 \mathrm{~km}$ to the north of where it has effectively been sampled once seismic data were migrated for dip. That seismic sampling could not extend as far north may be accounted for by an increased dip and the refraction by mantle material above the crustal wedge, both would prevent reflections from being focused back to surface with sufficient energy for the recorders on the fan.

No more crustal material is needed to fit the gravity data than is contained in the wedge-shaped root of the PAZ as defined seismically by the geometries of the shallow and the deep Moho and of the steeply dipping reflector in between, therefore interpreted as a mantle-crust boundary. This limits the extent of the lower part of the Iberian crust under the European crust to of the order of ten $\mathrm{km}$ north of the surface trace of the NPF.

Gravity fitting models also differ by the repartition within the crust itself of volumes of rocks of different origins. For the local positive anomaly in the vicinity of the NPZ, three geological possibilities are discussed by Torné et al. [1989]: lower crustal blocks, mantle slices, or dense rocks of the basement of the North Pyrenean Massifs. Two possible models, fitting gravity and seismic data, are presented (Figures $6 \mathrm{~b}$ and 6c); if the middle crustal structure beneath the NPF surface trace remains debatable, shape and composition of the crustal root of the chain are pretty well constrained.

There is a geographical coincidence of the gravity high of the NPZ with a series of clear, although of unelucidated nature, south dipping reflectors between 4 and $7 \mathrm{~s}$ TWT on the vertical reflection seismic profile [Choukroune et al., 1989, Figure 6]. In the same region, both wide-angle reflection fan profiles recorded in 1979 showed, apart from the Moho step, strong early phases with a $20-\mathrm{km}$ north-south extension just south of the NPF and reflected at a depth of the order of $15 \mathrm{~km}$ [Gallart et al., 1981, Figures 14 and 15]. The strength and character of the reflections seen with the two techniques could lead us to propose that they correspond to an important velocity and density contrast and have the same origin. If this hypothesis is well founded, shape and position of these reflectors favor the solution presented by Torné et al. [1989, Figure 5a], redrawn here as Figure $6 \mathrm{~b}$.

\section{CONCLUSION}

The internal structure of the lithosphere under the Pyrenees, which is thought to result from a sinistral drift of the Iberian plate along a preorogenic transform fault (the NPF), during Albian times, involving crustal thinning in the NPZ, followed by compression and fold belt formation between the Upper Cretaceous and the Upper Eocene, was until now controversial [Boillot and Capdevilla, 1976; Williams and Fischer, 1984; Deramond et al., 1985; Seguret and Daignières, 1986]. Wide-angle reflection, gravity and vertical reflection data of the ECORS survey used together rather strongly constrain this internal structure.

The main highlighted feature is the presence and strong dissymetry of a crustal root, which is modeled as a wedge-shaped body beneath $35 \mathrm{~km}$ depth. The 
Moho dips from the south and reaches a maximal depth of the order of 60-65 km just north of the surface trace of the NPF. Above the Iberian Moho and lower crust a very steeply northward inclined reflector indicates that this crustal material wedges out rapidly toward the north; it is overlain by a mantle wedge and the corresponding European crust above the $30-\mathrm{km}$-deep Moho, which is clearly interrupted to the south at the latitude of the NPF. The exact composition of the root remains debatable, as gravity data can be explained as well by a volume of heavy lower crustal material as by a more heterogeneous stack of slices of upper and lower crustal density materials [Torné et al., 1989]; as for seismic data, they can hardly solve the problem of local material velocity and constitution in such a geometrically complex volume.

The dissymetric root in the lithosphere may be viewed as a response of the crust to a northward subduction of the underlying mantle part (resulting in a suction of the more ductile lower crust material). Depending on prevailing temperature conditions and on possible previous compositional layering in the crust, levels of greater ductility may have concentrated the deformation in either the lower crust or the middle crust. In the first case the lower crust may have been sucked downward to build a homogeneous root, while the corresponding upper crust was thrust at the surface toward the north onto the European crust and to the south on itself. In the second case the root might consist of stacked slices containing lower and middle crustal material and possibly even mantle material.

Acknowledgments. Funding for this work has been provided in the frame of the French-Spanish ECORS Pyrenees project supported by INSU-CNRS, IFP, Elf-Aquitaine, Esso-Rep, CSIC, IGN,IGME,Hispanoil.

\section{REFERENCES}

Boillot G., and R. Capdevilla, The Pyrenees: Subduction and collision?, Earth Planet. Sci. Lett., 35, 151-160, 1976.

Choukroune P., and ECORS Team, The ECORS Pyrenean deep seismic profile: Reflection data and the overall structure of an orogenic belt, Tectonics, 8, 23-39, 1989.

Coron S., and A. Guillaume, Etude gravimétrique sur le Golfe de Gascogne et les Pyrénées, in Histoire Structurale du Golfe de Gascogne, pp IV.9.1IV.9.16, Technip, Paris, 1971.

Daignières M., J. Gallart, and E. Banda, Lateral variation of the crust in the North Pyrenean Zone, Ann. Géophys., 37, 435-456, 1981.

Daignières M., J. Gallart, E. Banda, and A. Hirn, Implications of the seismic structure for the orogenic evolution of the Pyrenees range, Earth Planet. Sci. Lett., 57, 88-110, 1982.

Deramond J., R.H. Graham, J.R. Hossack, P. Baby, and G. Crouzet, Nouveau modèle de la chaîne des
Pyrénées, C. R. Acad. Sci. Paris, 301, 1213-1216, 1985.

ECORS Pyrenees Team, The ECORS deep reflection seismic survey across the Pyrenees, Nature, 331, 508-511, 1988.

Gallart J., M. Daignières, E. Banda, E. Surinach, and A. Hirn, The Eastern Pyrenean Domain: Lateral variations at crust-mantle level, Ann. Géophys., 36, 141-158, 1980.

Gallart J., E. Banda, and M. Daignières, Crustal structure of the Paleozoic Axial Zone of the Pyrenees and transition to the North Pyrenean Zone, Ann. Géophys., 37, 457-480, 1981.

Hirn A., M. Daignières, J. Gallart, and M. Vadell, Explosion seismic sounding of throws and dips in the continental Moho, Geophys. Res. Lett., 7, 263-266, 1980.

Marchal F., Apport de la gravimétrie à la connaissance des structures profondes sous le Bassin Aquitain; Extension de la chaîne Hercynienne, thèse 3 ème cycle, 396 pp., Univ. of Montpellier, France, 1986.

Mattauer M., Les traits structuraux essentiels de la chaîne pyrénéenne, Rev. Geogr. Phys. et Geol.Dyn., 10, 3-11, 1968.

McGeary S., and M.R. Warner, Seismic profiling the continental lithosphere, Nature, 317, 795-797, 1985.

Seguret M., and M. Daignières, Crustal scale balanced cross-sections of the Pyrenees; Discussion, Tectonophysics, 129, 303-318, 1986.

Torné M., B. de Cabissole, R. Bayer, A. Casas, M. Daignières, and A. Rivero, Gravity constraints on the deep structures of the Pyrenean belt along the deep reflection seismic ECORS Pyrenees profile, Tectonophysics, in press, 1989.

Williams G.D., and M.W. Fischer, A balanced section across the Pyrenean orogenic belt, Tectonics, 3 , 773-780, 1984.

B. de Cabissole and M. Daignieres, Centre Géophysique et Géologique, Université de Montpellier, place E. Bataillon, 34060 Montpellier Cedex, France. J. Gallart, Instituto de Geologia Jaime Almera, Marti i Franques, s/n, Zona Universitaria Pedralbes, 08028 Barcelona, Spain.

A. Hirn, Institut de Physique du Globe, Université Pierre et Marie Curie, place Jussieu, 75005 Paris, France.

E. Surinach, Catedra de Geophisica, Universidad Complutense, Ciudad Universitaria, 28040 Madrid, Spain.

M. Torne, Servei Geologic de Catalunya, Diputacio, 92, 08015 Barcelona, Spain.

(Received February 23, 1988; revised April 15, 1989; accepted April 28, 1989.) 